Document downloaded from:

http://hdl.handle.net/10251/136095

This paper must be cited as:

Da Costa Serra, JF.; Chica, A. (2018). Catalysts based on Co-Birnessite and Co-Todorokite for the efficient production of hydrogen by ethanol steam reforming. International Journal of Hydrogen Energy. 43(35):16859-16865. https://doi.org/10.1016/j.ijhydene.2017.12.114

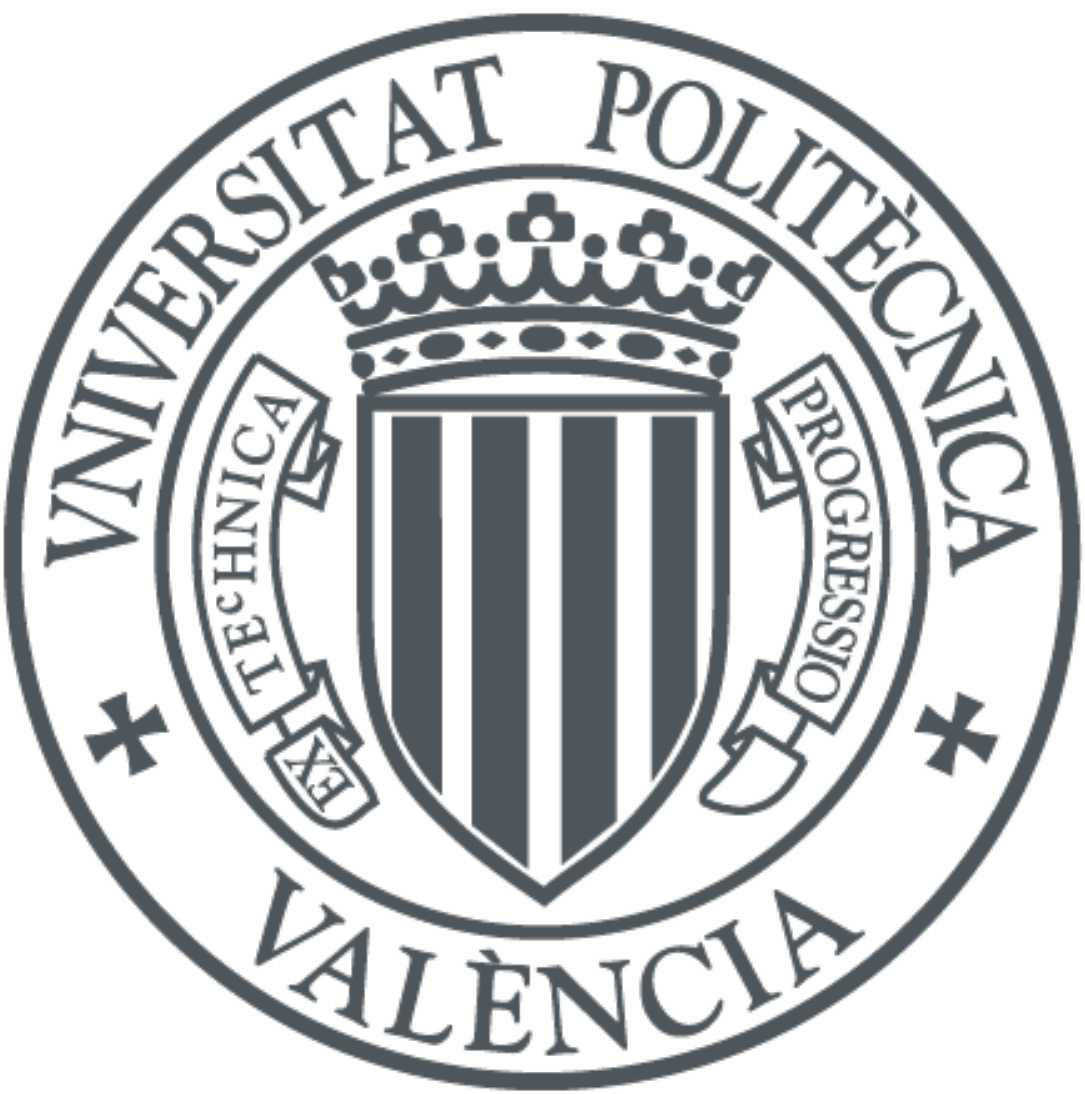

The final publication is available at

https://doi.org/10.1016/j.jijhdene.2017.12.114

Copyright Elsevier

Additional Information 


\title{
Catalysts based on Co-Birnessite and Co-Todorokite for the efficient production of hydrogen by ethanol steam reforming
}

\author{
J.F. Da Costa-Serra, A. Chica, * \\ Instituto de Tecnolgía Química (UPV-CSIC), Universitat Politècnica de València, Consejo Superior de \\ Investigaciones Científicas, Avenida de los naranjos s/n, Valencia 46022, Spain. \\ *Corresponding author. Tel.: +34 9638770 00-78508; fax: +34 963877809. \\ E-mail address: achica@itq.upv.es
}

\begin{abstract}
Two structured manganese oxides (Birnessite and Todorokite) containing Co have been studied in the steam reforming of ethanol. It has been found that both materials are active in the hydrogen production, exhibiting high values of conversion of ethanol and selectivities to hydrogen (100\% and 70\%, respectively). The best results have been obtained with the catalyst based on Todorokite material. Characterization by DRX, BET area, TPR and TEM has allowed to find that the excellent performance exhibited by this material could be attributed to the lower size of the Co metallic particles present in this sample (6 nm vs $12 \mathrm{~nm}$ in Birnessite). This lower size could be related to the especial microporous structure of Todorokite precursor, which would provide high-quality positions for the stabilization of the Co metal particles during calcination and reduction steps. Catalytic deactivation has also been considered. Deactivation was found higher for Todorokite-based catalyst, which presented the largest amount of deposited carbon (26.2 wt.\% for Co-TOD vs 10.6 wt.\% for Co-BIR). On the other hand, the degree of metal sintering was found similar in both catalysts. Therefore, the deactivation of the catalysts has been attributed primarily to the deposition of coke. The results presented here show that it is possible to prepare new catalysts based on manganese oxides with Birnessite and Todorokite structure and promoted with Co with high catalytic performance in the steam reforming of ethanol.
\end{abstract}

Keywords: Ethanol Steam Reforming, Hydrogen Production, Todorokite, Birnessite, Cobalt Catalyst.

\section{Introduction:}

Hydrogen is identified as a very promising energy carrier to satisfy energy needs while protecting the environment [1-3]. Unfortunately, it is not freely available in nature and it must be produced by some means, due to this reason, hydrogen cannot be considered an energy source. Currently, the majority of world $\mathrm{H}_{2}$ production is derived from fossil fuel-based conventional technologies [4-6]. These technologies generate greenhouse gas (GHG) emissions, concretely they have an emission factor of $\mathrm{CO}_{2}$ of 232,600 $\mathrm{Kg} / \mathrm{TJ}$ [7]. These high $\mathrm{CO}_{2}$ emissions favor the greenhouse effect, promoting climate change. Therefore, to realize the full benefits of a hydrogen economy-sustainability, increased energy security, diverse energy supply and reduced air pollution hydrogen must be produced cleanly, efficiently, and affordably from available renewable resources. In addition, using the $\mathrm{H}_{2}$ obtained from renewable energy as fuel the production of $\mathrm{CO}_{2}$ emissions will be decreased considerably. Hydrogen can be produced from biomass, a renewable and $\mathrm{CO}_{2}$-neutral energy source with respect to the greenhouse effect [8-10]. Specifically, reforming of renewable biomass feedstocks [11], such as ethanol, has become an increasingly important and active research area in view of hydrogen production [12-15]. Ethanol produced by biomass fermentation has a high ratio of water/ethanol $(\approx 13)$, suitable for steam reforming. Using ethanol directly gets an important economic and energy savings, since it will not be necessary to carry out the distillation of fermented to obtain pure ethanol. In comparison with other fuels, ethanol presents a series of advantages, 
since it is easier to store, handle and transport in a safe way due to is lower toxicity and volatility. In addition, from the environmental point of view, ethanol presents important advantages since it is metal-free and does not release pollutant gases $\left(\mathrm{SO}_{\mathrm{x}}, \mathrm{NO}_{\mathrm{x}}\right.$ and others) [16, 17]. Numerous reviews about the development of catalysts applied to ethanol steam reforming have been published lately [18-21]. Catalytic materials such as transition metals supported on oxides and precious metals supported on oxides are reported in these reviews. Among them, Co-based catalysts are widely accepted due to their appropriate low-cost compared to precious metals. For the steam reforming of ethanol, Co has emerged as an active metal catalyst for $\mathrm{C}-\mathrm{C}$ bond scission, which is an important characteristic [14]. Moreover, high ethanol conversions over Co catalysts supported on different supports have also been reported [21-27]. In general, the support is essential in the synthesis of efficient ethanol steam reforming catalysts since it helps in the distribution of metal in the catalyst and enhances its activity via metal-support interactions. In addition, synthesized methods and pretreatment conditions over supported cobalt catalysts are also important issues to prepared highly active and stable steam reforming catalysts. This way, the activity of the steam reforming catalyst can be improved achieving a good dispersion of metallic sites on the support, while coke formation could decrease using non-acidic supports that would avoid the ethanol dehydration reaction [27-31].

The chemical composition, textural properties of the support and synthesis method play important roles in the preparation of highly active steam reforming catalyst since they can improve the dispersion of metal catalysts [16], while decreasing their sinterization [32]. Recently, structured manganese oxides (SMO) are the subject of intense research as low cost, efficient, and environmentally friendly catalysts [33-35]. Among them SMO with layer and tunnel structure have received significant attention due to their excellent catalytic activity [36-40]. A literature review shows that SMO have been widely used as catalysts in oxidation reactions such as oxidation of $\mathrm{CO}$, toluene, VOCs, ethanol and the synthesis of benzoxazoles via the domino oxidation process [41-45]. SMO in ethanol steam reforming have not been much studied. However, it is possible that the special structure of SMO can favor a good distribution of the Co metal particles improving its catalytic activity in the ethanol steam reforming. In our previous work, it was found that SMO with $\mathrm{Ni}$ presented a high activity in the steam reforming of ethanol [46]. Thus, we presented now the results obtained in the ethanol steam reforming using Co metallic particles incorporated on SMO (Birnessite and Todorokite structures). The characterization of these Co-based catalysts has been completed and their more relevant physicochemical properties have been connected to their catalytic performance.

\section{Experimental:}

\subsection{Preparation of catalysts:}

The synthesis of Co-Birnessite and Co-Todorokite was carried out according to Onda et al. [47]. For CoBirnessite preparation a solution A containing $1.87 \mathrm{~g}$ of $\mathrm{Co}\left(\mathrm{NO}_{3}\right)_{2} \cdot 6 \mathrm{H}_{2} \mathrm{O}(\geq 98 \%$, Sigma-Aldrich) and 6.37 $\mathrm{g}$ of $\mathrm{MnCl}_{2} \cdot 4 \mathrm{H}_{2} \mathrm{O}(\geq 99 \%$, Sigma-Aldrich) in $100 \mathrm{~mL}$ of Milli-Q water was prepared and added dropwise over a period of $10 \mathrm{~min}$ at room temperature $(298 \mathrm{~K})$ into a solution $\mathrm{B}$ formed by $2.02 \mathrm{~g}$ of $\mathrm{KMnO}_{4}(\geq 99 \%$, Sigma-Aldrich) and $36 \mathrm{~g}$ of $\mathrm{NaOH}(\geq 98 \%$, Scharlab) in $100 \mathrm{~mL}$ of Milli-Q water. After the solutions were mixed, they were stirred for a total of $30 \mathrm{~min}$. The suspension was aged at room temperature for $24 \mathrm{~h}$, and it was filtered and washed with Milli-Q water until the $\mathrm{pH}$ was about 7. The resultant material was a layered Co-Birnessite material. This material was calcined in oven at $873 \mathrm{~K}$ and it referred to as Co-BIR.

Co-Todorokite was prepared using the obtained Co-Birnessite. It was ion-exchanged with $200 \mathrm{~mL}$ of a 0.1 $\mathrm{mol} / \mathrm{L} \mathrm{Co}\left(\mathrm{NO}_{3}\right)_{2} \cdot 6 \mathrm{H}_{2} \mathrm{O}$ ( $\geq 98 \%$, Sigma-Aldrich) aqueous solution at room temperature for $24 \mathrm{~h}$. The resultant layered sample was washed and filtered ten times with $200 \mathrm{~mL}$ of Milli-Q water. Finally, it was treated under hydrothermal conditions ( $433 \mathrm{~K}$ for $48 \mathrm{~h}$ in an autoclave lined with Teflon) and the resultant solid was washed and filtered with Milli-Q water, and dried at $333 \mathrm{~K}$ to yield Co-Todorkite. This material was calcined in oven at $873 \mathrm{~K}$ and labeled as Co-TOD.

\subsection{Characterization techniques:}

The cobalt content in the samples was determined by atomic absorption spectrophotometry (AAS) in a Varian Spectra A-10 Plus apparatus. 
Textural properties of the Co-BIR and Co-TOD materials were obtained from the nitrogen adsorption isotherms, which were measured using an ASAP 2420 apparatus (Micromeritics) at $77 \mathrm{~K}$. Before the analysis, $200 \mathrm{mg}$ of each pellitized sample $(0.25-0.40 \mathrm{~mm})$ were degassed at $673 \mathrm{~K}$ with high vacuum $(\sim 5 \times 10-6$ bar $)$ overnight. The BET surface area was calculated by using the Brunauer-Emmett-Teller equation, micropore volume was calculated by the t-plot method.

$\mathrm{X}$-ray diffraction was used to identify the nature of the crystalline manganese and cobalt oxides and metallic cobalt phases. XRD patterns were obtained at room temperature in a Philips X'pert diffractometer using monochromatized $\mathrm{CuK} \alpha$ radiation.

The reduction behavior of the catalysts was studied by temperature-programmed reduction (TPR) in a Micromeritics Autochem 2910 equipment. Between 30 and $100 \mathrm{mg}$ of sample, in the granulometry 0.25$0.40 \mathrm{~mm}$ were loaded in a quartz U-tube, a fixed bed between quartz wool. Samples were treated in Ar flow at room temperature for 30 minutes and then the circulating gas was replaced with $10 \% \mathrm{H}_{2}$ (vol)/ $\mathrm{Ar}(50$ $\mathrm{mL} / \mathrm{min}$ ) and the temperature was increased from room temperature to $973 \mathrm{~K}$ at a rate of $10 \mathrm{~K} / \mathrm{min}$. Downstream of the reactor, a 2-propanol/ $\mathrm{N}_{2}$ (l) trap was placed to retain the water formed in the reductions, and $\mathrm{H}_{2}$ consumption was recorded on a thermal conductivity detector (TCD), previously calibrated using the reduction of $\mathrm{CuO}$ as a reference.

The amount of carbon deposited in the catalysts after steam reforming reaction was determined by elemental analysis using a Carlo Erba 1106 analyzer.

The morphology and the metallic Co particles sizes were studied by transmission electron microscopy (TEM) using a JEM-1010 microscope.

\subsection{Catalytic study:}

Steam reforming experiments were carried out in a continuous fixed bed reactor at atmospheric pressure, $\mathrm{H}_{2} \mathrm{O} / \mathrm{EtOH}$ molar ratio of 13, GHSV $4700 \mathrm{~h}^{-1}\left(\mathrm{EtOH}+\mathrm{H}_{2} \mathrm{O}\right)$ and a range of temperatures between $673 \mathrm{~K}$ and $873 \mathrm{~K}$. Before reaction the catalysts were reduced "in situ" in flow of $\mathrm{H}_{2}\left(1.67 \mathrm{~mL} \cdot \mathrm{s}^{-1}\right)$ at $873 \mathrm{~K}$ for $2 \mathrm{~h}$.

In a typical catalytic test, the reactor was loaded with $0.3 \mathrm{~mL}$ of catalyst, $\sim 0.25 \mathrm{~g}$, (grain-size: $0.25-0.42$ $\mathrm{mm}$ ), diluted with $3 \mathrm{~g}$ of carborundum $(\mathrm{SiC})$ (grain-size: 0.60-0.80 mm). The water/ethanol mixture was fed from a pressurized container using a liquid flow controller (Bronkhorst), and vaporized at $473 \mathrm{~K}$ into a stream of nitrogen. The total gas flow was $2 \mathrm{~mL} \cdot \mathrm{s}^{-1}$. The catalytic studies were carried out at $673 \mathrm{~K}, 773 \mathrm{~K}$ and $873 \mathrm{~K}$, lasting for 5 hours in each temperature.

The analysis of the compounds of reaction was carried out online using a gas chromatograph (Varian 3800) equipped with two columns (TRB-5, L $=30 \mathrm{~m}, \mathrm{DI}=0.25 \mathrm{~mm}$; CarboSieve SII, $\mathrm{L}=3 \mathrm{~m}, \mathrm{DI}=2.1 \mathrm{~mm}$ ) and two detectors, a thermal conductivity (TCD) and flame ionization (FID).

The ethanol conversion and selectivity to the different reaction products were determined according to the Eqs. (1) and (2), where $\left(\mathrm{F}_{\mathrm{EtOH}}\right)_{0}$ is the flow of ethanol fed to the reactor $\left(\mathrm{mol} \cdot \mathrm{s}^{-1}\right),\left(\mathrm{F}_{\mathrm{EtOH}}\right)_{\mathrm{f}}$ the flow of ethanol that comes from the reactor and $\mathrm{F}_{\mathrm{j}}$ the flow of product $\mathrm{j}$ that comes from the reactor. Selectivity values were calculated as the molar percentage of the products obtained.

$$
\begin{gathered}
\text { Conv. }(\%, \mathrm{~mol})=\frac{\left(F_{E t O H}\right)_{0}-\left(F_{E t O H}\right)_{f}}{\left(F_{E t O H}\right)_{0}} \times 100(1) \\
\text { Selec. }(\%, m o l)=\frac{F_{j}}{\left(\sum F_{j}\right)_{\text {products }}} \times 100(2)
\end{gathered}
$$

\section{Results and discussion:}

\subsection{Characterization:}

Specific surface area and cobalt content of Co-BIR and Co-TOD are presented in Table 1. As it can be seen both materials present similar area and cobalt content. 
Tabla 1. Metal content and BET surface area of the catalysts studied in this work.

\begin{tabular}{lccc}
\hline Sample & $\begin{array}{c}\text { BET surface area } \\
\left(\mathbf{m}^{2} / \mathbf{g}\right)\end{array}$ & $\begin{array}{c}\text { Co, Nominal } \\
\text { composition, wt.\% }\end{array}$ & $\begin{array}{c}\text { Co, Determined } \\
\text { composition, wt.\% }\end{array}$ \\
\hline Co-BIR & 14 & 15.0 & 13.1 \\
Co-TOD & 11 & 15.0 & 12.7 \\
\hline
\end{tabular}

X-ray diffraction patterns of synthesized Co-Birnessite and Co-Todorokite materials are showed in Figure 1. As it can be seen all the diffraction peaks can be attributed to the Birnessite and Todorokite phases [47], suggesting that Co-Birnessite and Co-Todorokite has been correctly synthesized.

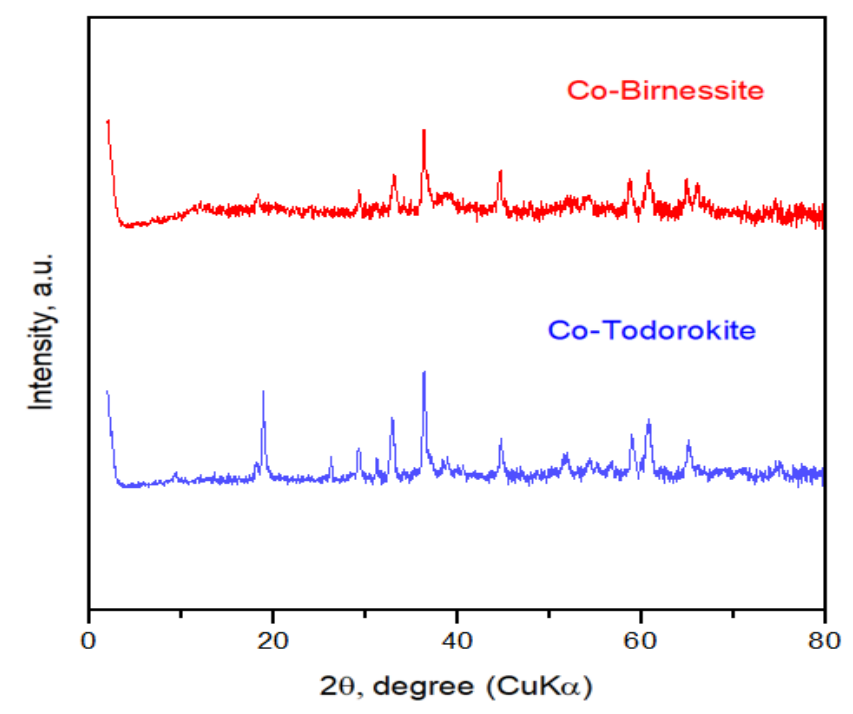

Fig. 1. XRD of Co-Birnessite and Co-Todorokite as they were synthesized.

Co-BIR and Co-TOD were calcined at $873 \mathrm{~K}$ and after reduced at $873 \mathrm{~K}$ before reaction. Figure 2 shows the XRD of the Co-BIR and Co-TOD materials after the calcination and reduction steps. As it can be seen the calcined materials showed similar XRD pattern with diffraction peaks corresponding to $\mathrm{Mn}_{3} \mathrm{O}_{4}$ [Ref. code 00-008-0017], and cobalt oxide ( $\mathrm{Co}_{3} \mathrm{O}_{4}$ phase [Ref. code 00-042-1467]).

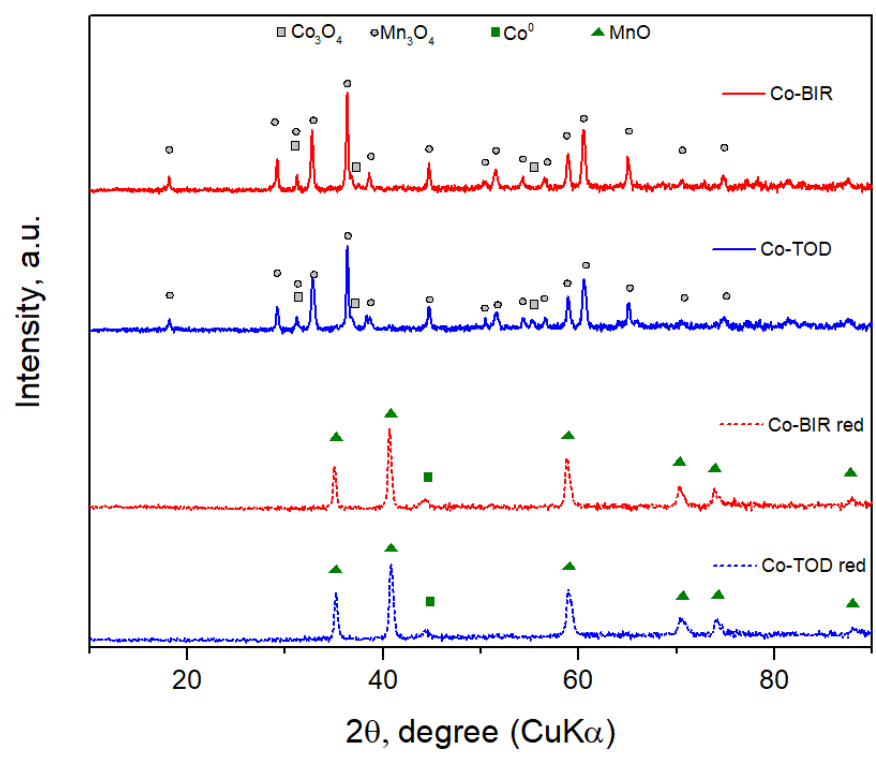

Fig. 2. XRD of the catalysts after calcination (Co-BIR and Co-TOD) and reduction (Co-BIR red and Co-TOD red) at $873 \mathrm{~K}$. 
After reduction with hydrogen at $873 \mathrm{~K}$, the peaks corresponding to cobalt oxide species disappear and appear those due to the reduced metallic cobalt phases [Ref. code 00-015-0806], Figure 2. The manganese oxide phase also change to more reduces forms (MnO [Ref. code 01-089-2804). Nevertheless, metallic manganese phases were not detected.

The size of the Co metallic particles present on reduced Co-BIR and Co-TOD was determined using the Scherrer equation [48]. They were found 14 and $7 \mathrm{~nm}$, respectively. Particle size was also determined by TEM [Figure $3 \mathrm{a}$ ) and b)]. In this case they were found $12 \mathrm{~nm}$ for Co-BIR and $6 \mathrm{~nm}$ for Co-TOD, quite similar to the sizes determined by XRD. The lower size of the Co metallic particle detected for the Co-TOD sample could be related to its particular morphology formed by small channels where the cobalt could be located. Thus, the microporous structure of this material can help to provide high-quality positions for the accommodation and stabilization of Co metallic particles during the reduction step avoiding their sinterization. On the contrary, the low porosity of the Birnessite structure could lead to a higher sinterization of Co during the reduction step, leading to higher metallic particle size, as it is observed.

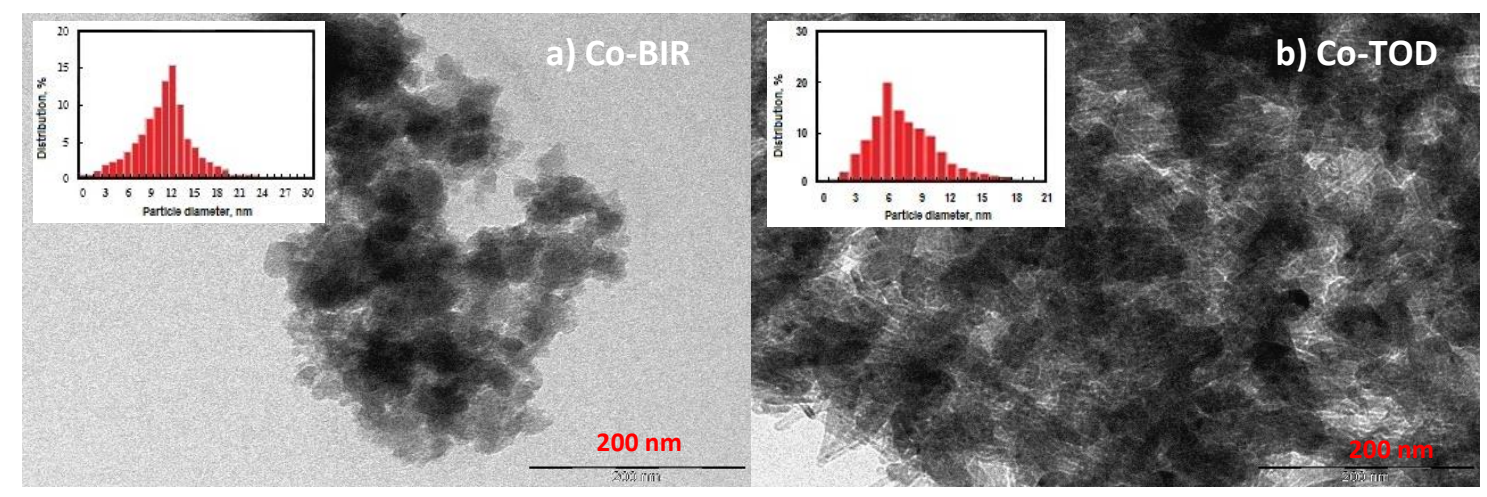

Fig. 3. TEM micrographs of the a) Co-BIR and b) Co-TOD after reduction at $873 \mathrm{~K}$.

The reduction behaviors of the Co-BIR and Co-TOD have been also studied by temperature programmed reduction (TPR). The corresponding reduction curves are show in Figure 4. As observed, Co-BIR and CoTOD present similar reduction profiles in all range of temperatures. The presence of Co in the catalysts does not have a significant influence in the reduction profile, which is attributed mainly to the reduction of the support in a much higher proportion [45, 49]. Nevertheless, it is possible to identify some peaks corresponding to the reduction of the oxidized species of cobalt (peaks Ia and IIa) and manganese (peak $\mathrm{Ib}$ ). In the case of the cobalt oxidized species, the first one at around $475 \mathrm{~K}$, can be attributed mainly to the reduction of $\mathrm{Co}_{3} \mathrm{O}_{4}$ to $\mathrm{CoO}$, Ia [50]. The second, one at around $750 \mathrm{~K}$, could be assigned mostly to the reduction $\mathrm{CoO}$ to $\mathrm{Co}$, IIa [50]. On the other hand, for the oxidized specie of manganese, the peak at around $660 \mathrm{~K}$, can be attributed to the reduction $\mathrm{Mn}_{3} \mathrm{O}_{4}$ to obtained $\mathrm{MnO}, \mathrm{Ib}$ [49, 51, 52]. The small differences found in the temperature reduction for the Co-BIR and Co-TOD could be related to the different interaction and size of the Co metallic particles detected for each support. Smaller particle size would favor the appearance of stronger metal-support interactions, increasing the reduction temperature. Indeed, the highest reduction temperatures were detected for the Co-TOD sample, which exactly showed the smallest Co metallic particle sizes. 


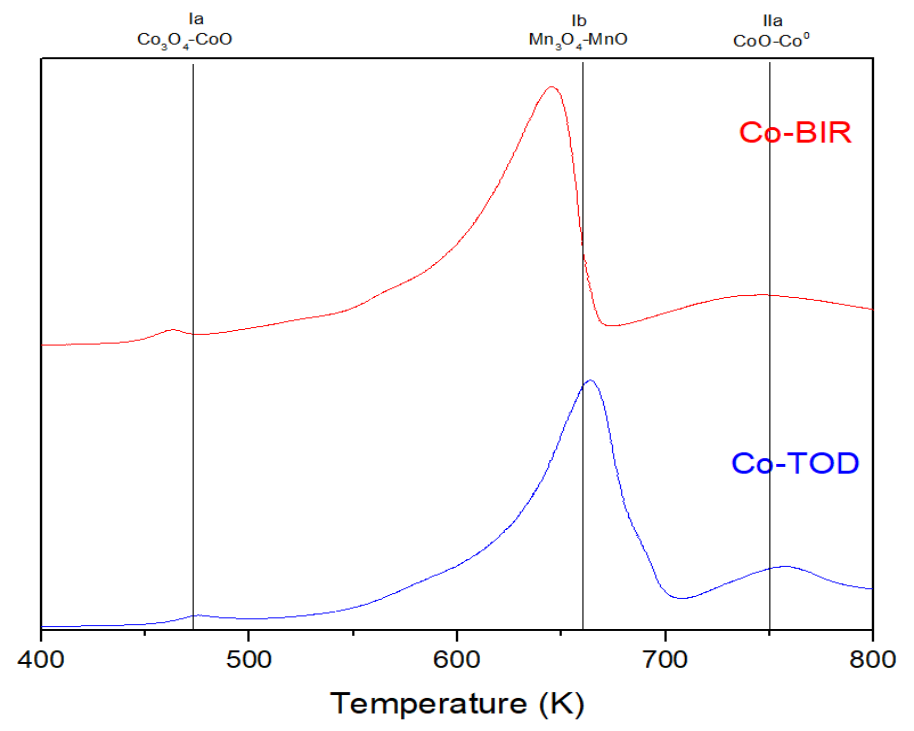

Fig. 4. TPR profiles of Co-BIR and Co-TOD.

\subsection{Catalytic activity:}

Catalytic data for each reaction temperature correspond to the steady state, which is achieved after 2 hours of reaction time. No deactivation was detected after the temperature study. It was corroborated by the determination of the catalytic activity at the reaction condition used initially, when the catalytic studied was started.

Figure $5 \mathrm{~A}$ ) shows the conversion of ethanol with the reaction temperature. As it can be seen Co-TOD material presents a higher catalytic activity in comparison with the Co-BIR material, especially at low reaction temperatures $(673 \mathrm{~K})$. Hydrogen selectivity was found high for both catalysts. However, small differences were found at higher temperatures (773-873 K), being the Co-TOD sample the most selective, Figure $5 \mathrm{~B}$ ). In general, it can be said that Co-TOD exhibits the best catalytic performance at the reaction conditions here studied. This greater activity could be related to the smaller size of its metallic Co particles $(6 \mathrm{~nm})$ compared to the size of the Co metallic particles supported on Co-BIR $(12 \mathrm{~nm})$. As it was explained before, in the characterization part, the differences in size of the Co metallic particles can be due to the special microchannel structure of Todorokite, which may favor a better distribution of metallic particle, avoiding their agglomeration in the reduction step. Therefore, these results seem to support the positive effect that microporous structure of Todorokite could have to prepare reforming catalysts with high activity in the steam reforming of ethanol. 

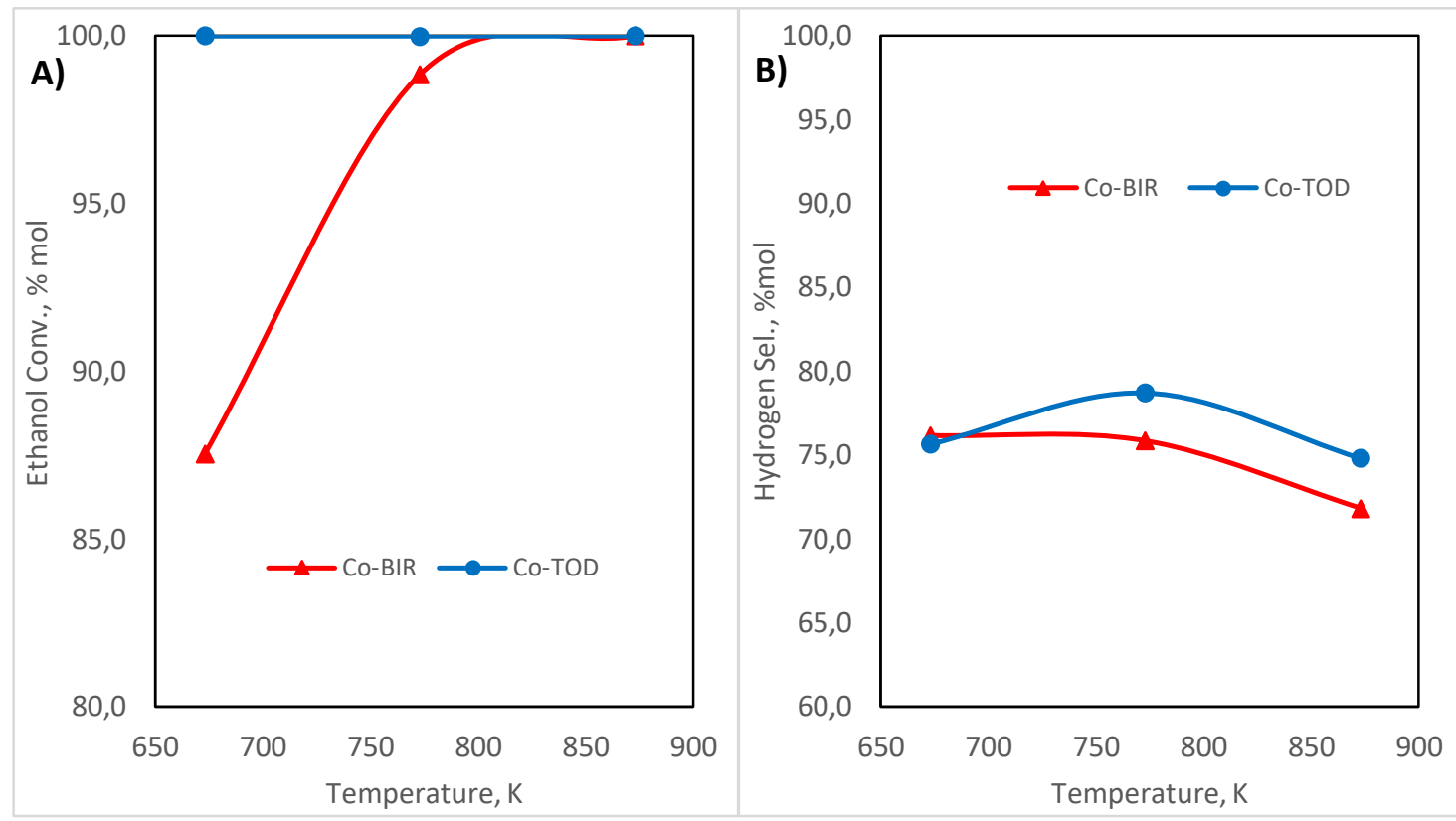

Fig. 5. A) Conversion of bioethanol versus reaction temperature. B) Hydrogen selectivity versus reaction temperature. Reaction conditions: $\mathrm{H}_{2} \mathrm{O} / \mathrm{EtOH}=13$, GHSV $=4700 \mathrm{~h}^{-1}$ and atmospheric pressure.

Products distribution have been also studied and they are showed in Table 2. As it can be seen SMO-based materials produce very low quantities of undesirable products (Table 2). Specifically, Co-TOD presents the lowest amount of $\mathrm{CH}_{4}, \mathrm{CO}$ and other byproducts $\left(\mathrm{C}_{2} \mathrm{H}_{4} \mathrm{O}\right.$ and $\left.\mathrm{C}_{3} \mathrm{H}_{6} \mathrm{O}\right)$. Again, the lower production of byproducts could be related to the smaller size of the metallic Co particles present in this sample.

Table 2. Catalytic results for the bioethanol steam reforming on Co-BIR and Co-TOD. Reaction conditions: $\mathrm{H}_{2} \mathrm{O} / \mathrm{EtOH}=13$, GHSV $=4700 \mathrm{~h}^{-1}$ and atmospheric pressure.

\begin{tabular}{cccccccc}
\hline Catalyst & $\mathbf{T} ., \mathbf{K}$ & $\mathbf{C H}_{\mathbf{4}}$ & $\mathbf{C O}$ & $\mathbf{C O}_{2}$ & $\mathbf{C}_{2} \mathbf{H}_{4}$ & $\mathbf{C}_{2} \mathbf{H}_{4} \mathbf{O}$ & $\mathbf{C}_{3} \mathbf{H}_{6} \mathbf{O}$ \\
\hline \multirow{2}{*}{ Co-BIR } & 673 & 1.0 & 0.9 & 20.3 & 0.0 & 1.6 & 0.0 \\
& 773 & 1.0 & 2.3 & 19.5 & 0.0 & 0.9 & 0.4 \\
& 873 & 3.0 & 8.4 & 16.4 & 0.1 & 0.2 & 0.1 \\
\hline \multirow{2}{*}{ Co-TOD } & 673 & 2.2 & 0.9 & 21.2 & 0.0 & 0.0 & 0.0 \\
& 773 & 0.8 & 1.5 & 19.0 & 0.0 & 0.0 & 0.0 \\
& 873 & 2.1 & 3.4 & 19.5 & 0.1 & 0.0 & 0.1 \\
\hline
\end{tabular}

Together to the activity and selectivity, stability is another important catalytic parameter to be considered. It is well known that the stability of a reforming catalyst is strongly influenced by the coke deposition and metal sintering [36]. The elemental analysis of the catalysts after $24 \mathrm{~h}$ of the reaction time shows that the amount of deposited coke is greater in the case of Co-TOD (Table 3), which presents a larger activity loss. This result suggests that the loss of activity may be directly related to the coke deposition. On the other hand, sinterization of the Co metallic particle has also been studied by TEM. Figure 6 a), b) shows the TEM of the samples after reaction. As it can be seen Co metallic particles present similar degree of sinterization in both samples (from $12 \mathrm{~nm}$ to $40 \mathrm{~nm}$ for Co-BIR and from $6 \mathrm{~nm}$ to $20 \mathrm{~nm}$ for Co-TOD). Nevertheless, the final size of the Co metallic particles remains still larger for Co-BIR sample. Thus, this sample should be presented a lower catalytic activity than the Co-TOD. However, the catalytic activity of this sample after $24 \mathrm{~h}$ is higher than the Co-TOD. These results suggest that the loss of activity in Co-TOD seem to be more influenced by the carbon deposition than by the sinterization of the metallic Co particles. 
Table 3. Catalytic results for the ethanol steam reforming on Co-BIR and Co-TOD. Ethanol conversion values obtained at two reaction times, $5 \mathrm{~h}$ and $24 \mathrm{~h}$. Deposited carbon after $24 \mathrm{~h}$ of reaction time. Reaction conditions: $\mathrm{H}_{2} \mathrm{O} / \mathrm{EtOH}=13, \mathrm{GHSV}=4700 \mathrm{~h}^{-1}$, atmospheric pressure and $773 \mathrm{~K}$.

\begin{tabular}{|c|c|c|c|c|c|c|}
\hline \multirow{2}{*}{ Catalyst } & \multicolumn{2}{|c|}{ Conv. EtOH, mol \% } & \multicolumn{2}{c|}{$\mathrm{H}_{2}$ Selectivity, mol\% } & C, wt.\% of catalyst & \% C, deposited/feed \\
\cline { 2 - 7 } & $5 \mathrm{~h}$ & $24 \mathrm{~h}$ & $5 \mathrm{~h}$ & $24 \mathrm{~h}$ & $24 \mathrm{~h}$ & $24 \mathrm{~h}$ \\
\hline Co-BIR & 98.9 & 94.6 & 69.9 & 69.8 & 10.6 & 1.3 \\
\hline Co-TOD & 99.9 & 87.9 & 75.0 & 74.9 & 26.2 & 3.9 \\
\hline
\end{tabular}

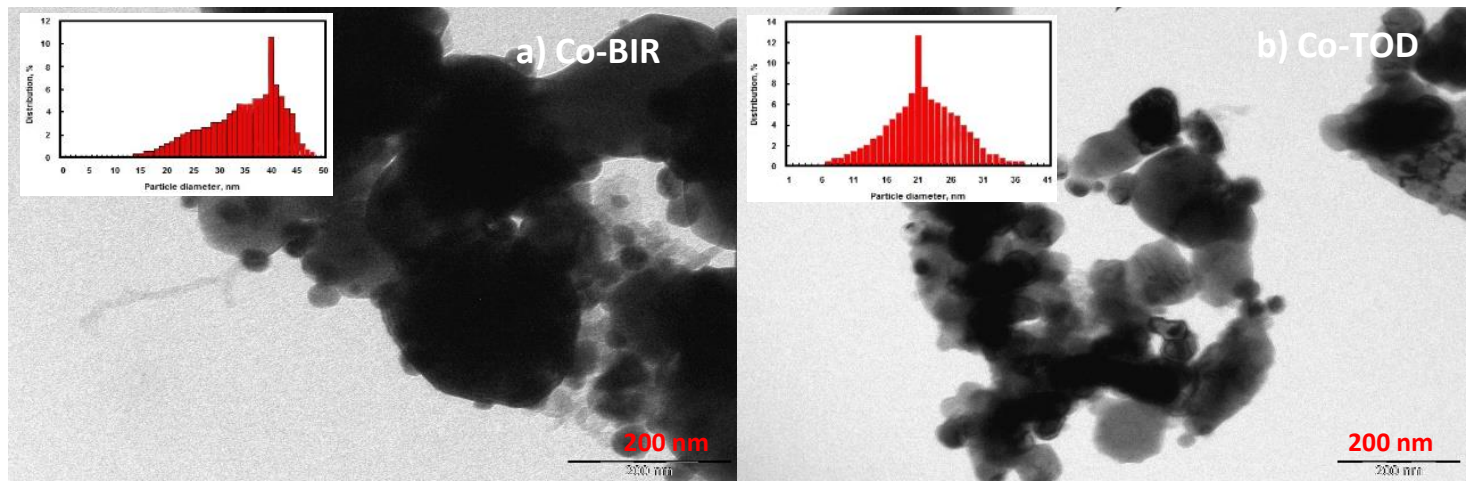

Fig. 6. a), b) TEM micrographs of the Co-BIR and Co-TOD after $24 \mathrm{~h}$ of reaction time.

All the results presented here show that it is possible to prepared new ethanol steam reforming catalysts based on structured manganese oxides (type Birnessite and Todorokite) as support of cobalt catalyst with high catalytic activity and hydrogen selectivity, able to reduce the formation of $\mathrm{CO}$ and $\mathrm{CH}_{4}$.

\section{Conclusions:}

Structured manganese oxides type Birnessite and Todorokite with Co have been used by the first time as catalysts in the steam reforming of ethanol. Resulting catalysts (Co-BIR and Co-TOD) have exhibited a higher catalytic activity and hydrogen selectivity with low production of not desired byproducts such as $\mathrm{CO}$ and $\mathrm{CH}_{4}$. Specifically, the Todorokite-based material (Co-TOD) exhibited the better catalytic performance at low reaction times $(5 \mathrm{~h})$, without undesirable byproducts, what seems to be related to the smaller Co metallic particles present in this material, $6 \mathrm{~nm}$ versus $12 \mathrm{~nm}$ for Co-BIR. The degree of sintering in both materials after reaction was found similar. However, at larger reaction times ( $24 \mathrm{~h})$ the Co-TOD sample generated large amounts of carbon, leading to a higher deactivation by coke deposition.

\section{Acknowledgements}

The doctor Javier Francisco Da Costa Serra acknowledges the CSIC for granted the scholarship predoctoralJAE-CSIC. Moreover, Electronic Microscopy Service of UPV for TEM images.

\section{References}

[1]. Liguras, D.K., D.I. Kondarides, and X.E. Verykios, Production of hydrogen for fuel cells by steam reforming of ethanol over supported noble metal catalysts. Applied Catalysis B: Environmental, 2003. 43(4): p. 345-354. 
[2]. Sohn, H. and U.S. Ozkan, Cobalt-Based Catalysts for Ethanol Steam Reforming: An Overview. Energy \& Fuels, 2016. 30(7): p. 5309-5322.

[3]. da Silva Veras, T., et al., Hydrogen: Trends, production and characterization of the main process worldwide. International Journal of Hydrogen Energy, 2017. 42(4): p. 20182033.

[4]. Muradov, N., Low to near-zero $\mathrm{CO} 2$ production of hydrogen from fossil fuels: Status and perspectives. International Journal of Hydrogen Energy, 2017. 42(20): p. 1405814088.

[5]. Tamošiūnas, A., et al., Glycerol steam reforming for hydrogen and synthesis gas production. International Journal of Hydrogen Energy, 2017. 42(17): p. 12896-12904.

[6]. Orfila, M., et al., Thermochemical hydrogen production using manganese cobalt spinels as redox materials. International Journal of Hydrogen Energy, 2017. 42(19): p. 1353213543.

[7]. Weger, L., A. Abánades, and T. Butler, Methane cracking as a bridge technology to the hydrogen economy. International Journal of Hydrogen Energy, 2017. 42(1): p. 720-731.

[8]. Maggio, G., S. Freni, and S. Cavallaro, Light alcohols/methane fuelled molten carbonate fuel cells: a comparative study. Journal of Power Sources, 1998. 74(1): p. 17-23.

[9]. Ni, M., et al., An overview of hydrogen production from biomass. Fuel Processing Technology, 2006. 87(5): p. 461-472.

[10]. F. Brown, L., A comparative study of fuels for on-board hydrogen production for fuelcell-powered automobiles. International Journal of Hydrogen Energy, 2001. 26(4): p. 381-397.

[11]. Ma, F. and M.A. Hanna, Biodiesel production: a review1. Bioresource Technology, 1999. 70(1): p. 1-15.

[12]. Ni, M., D.Y.C. Leung, and M.K.H. Leung, A review on reforming bio-ethanol for hydrogen production. International Journal of Hydrogen Energy, 2007. 32(15): p. 32383247.

[13]. Haryanto, A., et al., Current Status of Hydrogen Production Techniques by Steam Reforming of Ethanol: A Review. Energy \& Fuels, 2005. 19(5): p. 2098-2106.

[14]. Vaidya, P.D. and A.E. Rodrigues, Insight into steam reforming of ethanol to produce hydrogen for fuel cells. Chemical Engineering Journal, 2006. 117(1): p. 39-49.

[15]. Huber, G.W., S. Iborra, and A. Corma, Synthesis of Transportation Fuels from Biomass: Chemistry, Catalysts, and Engineering. Chemical Reviews, 2006. 106(9): p. 4044-4098.

[16]. Fierro, V., et al., Ethanol oxidative steam reforming over Ni-based catalysts. Journal of Power Sources, 2005. 145(2): p. 659-666.

[17]. Comas, J., et al., Bio-ethanol steam reforming on Ni/Al2O3 catalyst. Chemical Engineering Journal, 2004. 98(1-2): p. 61-68.

[18]. Mattos, L.V., et al., Production of Hydrogen from Ethanol: Review of Reaction Mechanism and Catalyst Deactivation. Chemical Reviews, 2012. 112(7): p. 4094-4123.

[19]. Sun, J. and Y. Wang, Recent Advances in Catalytic Conversion of Ethanol to Chemicals. ACS Catalysis, 2014. 4(4): p. 1078-1090.

[20]. LeValley, T.L., A.R. Richard, and M. Fan, The progress in water gas shift and steam reforming hydrogen production technologies - A review. International Journal of Hydrogen Energy, 2014. 39(30): p. 16983-17000.

[21]. Contreras, J.L., et al., Catalysts for $\mathrm{H} 2$ production using the ethanol steam reforming (a review). International Journal of Hydrogen Energy, 2014. 39(33): p. 18835-18853.

[22]. de la Peña O'Shea, V.A., et al., Development of robust Co-based catalysts for the selective $\mathrm{H} 2$-production by ethanol steam-reforming. The Fe-promoter effect. International Journal of Hydrogen Energy, 2008. 33(13): p. 3601-3606.

[23]. Yu, S.-W., et al., The effect of accessible oxygen over Co3O4-CeO2 catalysts on the steam reforming of ethanol. International Journal of Hydrogen Energy, 2014. 39(35): p. 20700-20711. 
[24]. Da Costa-Serra, J.F. and A. Chica, Bioethanol steam reforming on Co/ITQ-18 catalyst: Effect of the crystalline structure of the delaminated zeolite ITQ-18. International Journal of Hydrogen Energy, 2011. 36(6): p. 3862-3869.

[25]. Zhao, X. and G. Lu, Modulating and controlling active species dispersion over Ni-Co bimetallic catalysts for enhancement of hydrogen production of ethanol steam reforming. International Journal of Hydrogen Energy, 2016. 41(5): p. 3349-3362.

[26]. Ando, Y. and K. Matsuoka, Role of Fe in Co-Fe particle catalysts for suppressing $\mathrm{CH} 4$ production during ethanol steam reforming for hydrogen production. International Journal of Hydrogen Energy, 2016. 41(30): p. 12862-12868.

[27]. Palma, V., et al., On the activity of bimetallic catalysts for ethanol steam reforming. International Journal of Hydrogen Energy, 2013. 38(16): p. 6633-6645.

[28]. Vicente, J., et al., Coke deactivation of Ni and Co catalysts in ethanol steam reforming at mild temperatures in a fluidized bed reactor. International Journal of Hydrogen Energy, 2014. 39(24): p. 12586-12596.

[29]. Vicente, J., et al., Reaction pathway for ethanol steam reforming on a Ni/SiO2 catalyst including coke formation. International Journal of Hydrogen Energy, 2014. 39(33): p. 18820-18834.

[30]. Shejale, A.D. and G.D. Yadav, Cu promoted Ni-Co/hydrotalcite catalyst for improved hydrogen production in comparison with several modified Ni-based catalysts via steam reforming of ethanol. International Journal of Hydrogen Energy, 2017. 42(16): p. 11321-11332.

[31]. Arslan, A. and T. Doğu, Effect of calcination/reduction temperature of Ni impregnated CeO2-ZrO2 catalysts on hydrogen yield and coke minimization in low temperature reforming of ethanol. International Journal of Hydrogen Energy, 2016. 41(38): p. 16752-16761.

[32]. Chica, A. and S. Sayas, Effective and stable bioethanol steam reforming catalyst based on Ni and Co supported on all-silica delaminated ITQ-2 zeolite. Catalysis Today, 2009. 146(1-2): p. 37-43.

[33]. Suib, S.L., Structure, porosity, and redox in porous manganese oxide octahedral layer and molecular sieve materials. Journal of Materials Chemistry, 2008. 18(14): p. 16231631.

[34]. Sarmah, B., et al., Green and Sustainable Tandem Catalytic Approach for FineChemicals Synthesis Using Octahedral MnO2 Molecular Sieve: Catalytic Activity versus Method of Catalyst Synthesis. ACS Sustainable Chemistry \& Engineering, 2015. 3(11): p. 2933-2943.

[35]. Said, S., et al., Preparation of nano-structured cryptomelane materials for catalytic oxidation reactions. Journal of Nanostructure in Chemistry, 2016. 6(2): p. 171-182.

[36]. Sithambaram, S., et al., Tandem catalysis: Direct catalytic synthesis of imines from alcohols using manganese octahedral molecular sieves. Journal of Catalysis, 2008. 253(2): p. 269-277.

[37]. Ghosh, R., et al., Role of Manganese Oxide Octahedral Molecular Sieves in Styrene Epoxidation. The Journal of Physical Chemistry B, 2006. 110(14): p. 7592-7599.

[38]. Sun, $\mathrm{H}$., et al., The role of lattice oxygen on the activity and selectivity of the OMS-2 catalyst for the total oxidation of toluene. Chemical Engineering Journal, 2015. 270: p. 58-65.

[39]. Liu, F., et al., UV-Vis-Infrared Light Driven Thermocatalytic Activity of Octahedral Layered Birnessite Nanoflowers Enhanced by a Novel Photoactivation. Advanced Functional Materials, 2016. 26(25): p. 4518-4526.

[40]. Hu, R., et al., Selective oxidation of CO in rich hydrogen stream over Ag/OMS-2 catalyst. International Journal of Hydrogen Energy, 2011. 36(1): p. 64-71. 
[41]. Liu, L., et al., Effect of preparation method on the surface characteristics and activity of the Pd/OMS-2 catalysts for the oxidation of carbon monoxide, toluene, and ethyl acetate. Applied Surface Science, 2017. 396: p. 599-608.

[42]. Wang, R. and J. Li, Effects of Precursor and Sulfation on OMS-2 Catalyst for Oxidation of Ethanol and Acetaldehyde at Low Temperatures. Environmental Science \& Technology, 2010. 44(11): p. 4282-4287.

[43]. Mao, M., et al., Extremely efficient full solar spectrum light driven thermocatalytic activity for the oxidation of VOCS on OMS-2 nanorod catalyst. Applied Catalysis B: Environmental, 2015. 174: p. 496-503.

[44]. Meng, X., et al., OMS-2-Supported Cu Hydroxide-Catalyzed Benzoxazoles Synthesis from Catechols and Amines via Domino Oxidation Process at Room Temperature. The Journal of Organic Chemistry, 2017. 82(13): p. 6922-6931.

[45]. Yang, J., et al., Cobalt-Doped K-OMS-2 Nanofibers: A Novel and Efficient WaterTolerant Catalyst for the Oxidation of Carbon Monoxide. ChemCatChem, 2017. 9(7): p. 1163-1167.

[46]. Fuertes, A., J.F. Da Costa-Serra, and A. Chica, New Catalysts based on Ni-Birnessite and Ni-Todorokite for the Efficient Production of Hydrogen by Bioethanol Steam Reforming. Energy Procedia, 2012. 29: p. 181-191.

[47]. Onda, A., et al., Synthesis of manganese oxide octahedral molecular sieves containing cobalt, nickel, or magnesium, and the catalytic properties for hydration of acrylonitrile. Applied Catalysis A: General, 2007. 321(1): p. 71-78.

[48]. Cullity, B.D., Elements of X-ray Diffraction. Addison-Wesley. 1878.

[49]. Hernández, W.Y., et al., Modified cryptomelane-type manganese dioxide nanomaterials for preferential oxidation of $\mathrm{CO}$ in the presence of hydrogen. Catalysis Today, 2010. 157(1-4): p. 160-165.

[50]. Zhao, W., et al., Enhanced catalytic ozonation over reduced spinel CoMn2O4 for NOx removal: active site and mechanism analysis. RSC Advances, 2016. 6(116): p. 115213115221.

[51]. Sun, H., et al., Catalytic oxidation of toluene over manganese oxide octahedral molecular sieves (OMS-2) synthesized by different methods. Chemical Engineering Journal, 2011. 178: p. 191-196.

[52]. Ye, Q., et al., A comparative investigation on catalytic oxidation of $\mathrm{CO}$, benzene, and toluene over birnessites derived from different routes. Applied Surface Science, 2014. 317: p. 892-901. 